\title{
Penerapan Project Based Learning (PjBL) Terbimbing untuk Meningkatkan Keaktifan dan Pemahaman Siswa pada Konsep Momentum, Impuls, dan Tumbukan
}

\author{
L. Puspitasari, B. Astuti*, dan Masturi \\ Program Studi Pendidikan Fisika, Universitas Negeri Semarang, Indonesia \\ *Email:b_astuti79@mail.unnes.ac.id
}

Received: January 8th, 2020. Accepted: July 15th 2020. Published: August 31 th, 2020

\begin{abstract}
Abstrak
Penelitian ini bertujuan untuk menganalisis peningkatkan keaktifan dan pemahaman konsep siswa setelah diterapkan model Project Based Learning (PjBL) terbimbing. Metode penelitian yang digunakan adalah desain pre-experimental one group pretest-postest. Instrumen penelitian meliputi instrumen tes dan non-tes. Instrumen tes pada penelitian ini yaitu soal pemahaman konsep pilihan ganda beralasan. Instrumen nontes menggunakan lembar observasi keaktifan siswa. Keaktifan dan pemahaman konsep siswa dianalisis menggunakan uji $\mathrm{N}$ Gain. Signifikansi peningkatan keaktifan dan pemahaman konsep siswa dianalisis menggunkan uji wilcoxon mathced pairs. Hasil analisis data menunjukkan bahwa keaktifan dan pemahaman konsep siswa pada materi Momentum, Impuls, dan Tumbukan setelah diterapkan PjBL terbimbing mengalami peningkatan rendah dengan $N$-Gain sebesar 0,20 dan 0,22. Hasil uji signifikansi keaktifan dan pemahaman konsep siswa didapatkan nilai sebesar 0,041 dan 0,000 $(<0,050)$. Berdasarkan hasil analisis maka dapat disimpulkan bahwa penerapan model pembelajaran Project Based Learning terbimbing mampu meningkatkan keaktifan dan pemahaman konsep siswa secara signifikan pada materi Momentum, Impuls dan Tumbukan di SMA Nurul Islami.
\end{abstract}




\begin{abstract}
This study aims to analyze the increase in students' activeness and conceptual understanding after the guided Project Based Learning (PjBL) model is applied. The research method used was a pre-experimental one group pretest-postest design. The research instruments included test and non-test instruments. The test instrument in this study was a reasoned multiple choice. The non-test instrument uses student activeness observation sheets. Students' activeness and conceptual understanding were analyzed using the N-Gain test. The significance of increasing students' activeness and understanding of concepts was analyzed using the Wilcoxon mathced pairs test. The results of the data analysis showed that the students' activeness and conceptual understanding of the Momentum, Impulse, and Collision material after being applied to guided PjBL experienced a low increase with N-Gain of 0.20 and 0.22 . The results of the significance test of students' activeness and conceptual understanding were obtained values of 0.041 and $0.000(<0.050)$. Based on the results of the analysis, it can be concluded that the implementation of the guided Project Based Learning model was able to significantly increase the activeness and understanding of students' concepts in the material Momentum, Impulse and Collision at Nurul Islami High School. @2020PERJ
\end{abstract}

Keyword: Activity; concept understanding; Project Based Learning.

\section{PENDAHULUAN}

Hasil studi Trends in Intenasional Mathematic and Science Study (TIMSS) tahun 2011 pada jenjang sekolah menengah menyatakan bahwa Indonesia masuk ke dalam kategori rendah pada bidang matematika dan sains. Nilai ratarata Matematika sebesar 386 dan nilai rata-rata Sains sebesar 406, sementara nilai rata rata skor internasional sebesar 500 (Martin \& Mullis, 2012). Hal ini menunjukan bahwa kemampuan siswa Indonesia masih jauh di bawah rata-rata. Pada tahun 2015, Pusat Penilaian Pendidikan Badan Penelitian dan Pengembangan menyatakan bahwa kemampuan siswa Indonesia dalam mengerjakan soal TIMSS masih sangat minim pada soal-soal dalam domain bernalar. Siswa harus dibiasakan untuk memecahkan soal pada domain kognitif penalaran agar siswa terbiasa berpikir lebih dari sekedar hafalan. Menurut 
Purwati \& Handayanto (2016), terdapat korelasi antara penalaran dan pemahaman konsep siswa. Peningkatan

kemampuan penalaran siswa akan diikuti meningkatnya pemahaman konsep siswa, dan sebaliknya; sehingga untuk meningkatkan penalaran siswa, pemahaman konsep perlu ditingkatkan.

Fisika merupakan pelajaran yang berorientasi pada konsep. Suseno (2014) menyatakan bahwa materi-materi fisika memiliki konsep yang abstrak. Hal tersebut sering menjadi kendala bagi guru dalam menyampaikan materi kepada siswa, sehingga siswa belum optimal dalam memahami konsep yang dijelaskan oleh guru. Pemahaman yang kurang tentunya mengakibatkan minat siswa dalam belajar fisika menjadi rendah, sehingga mempengaruhi penguasaan konsep dalam menyelesaikan suatu persoalan.

Cara yang dapat dilakukan untuk meningkatkan pemahaman konsep siswa yaitu dengan memberikan tugas/proyek. Melalui proyek, siswa dapat menemukan sendiri konsep fisika dengan mengkonstruksi pengetahuan sendiri (Sari \& Sutikno, 2015). Fitrianingrum \& Sarwi (2016) juga menyatakan hal serupa, bahwa proyek merupakan alat penunjang yang dapat mendukung pemahaman konsep siswa.

Keaktifan siswa juga dapat memberikan pengaruh positif pada proses belajar (Wibowo, 2016). Siswa yang aktif cenderung akan lebih paham terhadap materi yang dipelajari, sehingga lebih mudah dalam memecahkan masalah. Penelitian Septialamsyah (2014) juga menyatakan bahwa keaktifan siswa mampu membangun kemampuan pemahaman konsep siswa; sedangkan Late \& Sutopo (2017) menyatakan bahwa pemahaman konsep siswa meningkat karena siswa diarahkan berperan aktif dalam proses pembelajaran. Oleh karena itu, perlu adanya pembelajaran yang mampu merangsang keaktifan siswa. Salah satu alternatif yang dapat digunakan untuk merangsang keaktifan siswa adalah dengan membuat proyek.

Model pembelajaran yang diterapkan dengan membentuk kelompok-kelompok kecil dan menghasilkan suatu proyek adalah Project Based Learning (PjBL). Model Project Based Learning juga mampu meningkatkan pemahaman konsep dan keaktifan siswa (Winarti, 2014; Suranti \& Gunawan, 2016; Julianti \& Wahyono, 2016). Proses pemahaman konsep terjadi saat siswa menyelesaikan proyek yang diberikan guru. Pemahaman konsep akan semakin baik ketika siswa melakukan presentasi terkait proyek yang telah dibuat (Afifah \& Sugianto, 2017). Selain itu, Irfianti \& Khanafiyah (2016) menyatakan bahwa untuk mencapai pemahaman konsep, guru perlu memicu proses berpikir siswa 
dengan memberikan pertanyaanpertanyaan yang berkaitan dengan materi. Keaktifan siswa juga dapat dilihat selama proses pembuatan proyek. Hal tersebut sesuai dengan pernyataan Sunyoung \& Capraro (2012) yang menyatakan bahwa fitur utama PjBL adalah memberdayakan siswa untuk membangun pembelajaran aktif. Ramadhani \& Santosa (2013) juga menyatakan bahwa model PjBL dapat meningkatkan kualitas pembelajaran, dengan keaktifan siswa adalah indikator utamanya. Model PjBL memberikan kesempatan pada siswa untuk lebih aktif belajar karena siswa didorong aktif dalam proses bertanya, menginvestigasi, menjelaskan, dan berinteraksi dengan permasalahan yang diberikan oleh guru (Yulianto, A., A. Fatchan, 2017). Proyek yang dihasilkan akan dipresentasikan di hadapan siswa yang lain sehingga melatih kemampuan komunikasi verbal siswa.

Hasil observasi dan wawancara dengan guru mata pelajaran fisika di SMA Nurul Islami menunjukkan bahwa pembelajaran fisika di kelas masih menerapkan teacher centered. Selain itu, berdasarkan hasil wawancara dengan siswa SMA Nurul Islami diperoleh informasi bahwa lebih dari 50\% siswa tidak suka dengan pelajaran fisika. Siswa menyatakan fisika adalah pelajaran dengan banyak rumus dan soal yang susah. Harapan siswa untuk pembelajaran fisika antara lain: banyak latihan soal, belajar sambil bermain, dan sesekali dilakukan praktikum.

Kurikulum 2013 mengarahkan agar siswa memperoleh pengalaman langsung ketika kegiatan pembelajaran dilakukan di kelas. Kendala yang dialami sekolah salah satunya adalah siswa masih belum mampu belajar secara mandiri, termasuk di SMA Nurul Islami. Oleh karena itu, perlu adanya bimbingan dari guru dalam pelaksaan pembelajaran, terutama pada penerapan model PjBL. Hal tersebut didasarkan pada pernyataan Wijanarko \& Supardi (2017) yang menyatakan bahwa bimbingan dalam kegiatan belajar mengajar diperlukan untuk mencapai tujuan pembelajaran yang diharapkan. Alasan perlunya bimbingan dalam kegiatan pembelajaran adalah terdapat perbedaan pada: 1) motivasi belajar antara siswa yang satu dengan siswa lainnya; 2) kemampuan atau kecerdasan dan latar belakang siswa; 3) proses kinerja ilmiah dalam pembuatan proyek menuntut siswa untuk berperan aktif dan kritis akan tetapi tidak semua melakukan secara mandiri, sehingga perlu adanya bimbingan oleh guru.

Berdasarkan permasalahan yang telah diuraikan, perlu dilakukan penelitian tentang penerapan Project Based Learning terbimbing untuk meningkatkan keaktifan dan pemahaman konsep siswa. Tujuan penelitian ini adalah untuk menganalisis peningkatan keaktifan 
dan pemahaman konsep siswa setelah diterapkan model Project Based Learning terbimbing.

\section{METODE PENELITIAN}

Penelitian ini dilaksanakan di SMA Nurul Islami, Semarang. Teknik pengambilan sampel menggunakan purposive sampling, dengan sampel yang diambil adalah siswa kelas $X$ MIPA. Penelitian ini menggunakan metode eksperimen dengan desain pre-experimental one group pretestpostest. Instrumen penelitian meliputi instrumen tes dan non-tes. Instrumen tes pada penelitian ini yaitu soal pemahaman konsep pilihan ganda beralasan dan instrumen non-tes yaitu lembar observasi keaktifan siswa.

Data yang diperoleh adalah nilai hasil pretest-postest dan lembar observasi keaktifan. Pemahaman konsep siswa dianalisis menggunakan uji N-Gain dari hasil pretest-postest siswa. Keaktifan siswa dianalisis dengan uji N-Gain dari hasil observasi keaktifan siswa. Uji signifikansi peningkatan pemahaman konsep siswa dianalisis menggunkan uji wilcoxon mathced pairs.

\section{HASIL DAN PEMBAHASAN}

\section{Keaktifan Siswa}

Peningkatan keaktifan siswa ditentukan berdasarkan hasil observasi kegiatan siswa pada setiap pertemuan. Hasil analisis keaktifan siswa ditunjukkan pada Gambar 1. Aspek keaktifan siswa yang diamati adalah visual activity, verbal activity, listening activity, writting activity, dan mental visual activity.

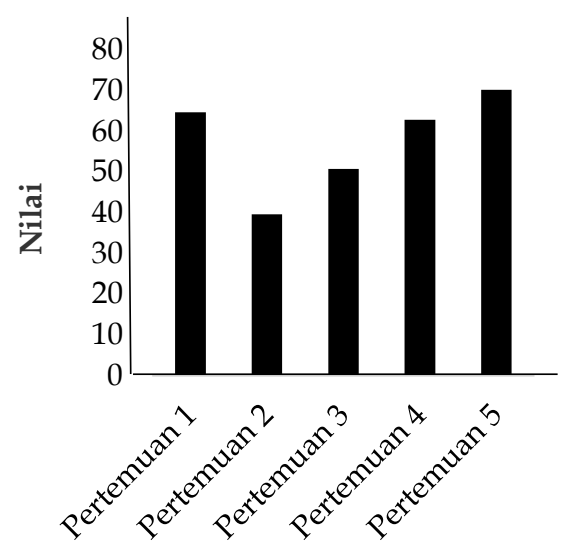

Gambar 1. Hasil Analisis Keaktifan Siswa.

Pada Gambar 1 terlihat bahwa keaktifan siswa pada pertemuan ke dua mengalami penurunan dari pertemuan pertama, akan tetapi pada pertemuan selanjutnya selalu mengalami peningkatan. Hal ini dikarenakan siswa baru merasakan model pembelajaran yang berbeda dari model yang biasa diterapkan oleh guru fisika sehingga membuat kesiapan belajar siswa kurang. Persentase keaktifan siswa pada pertemuan I, II, III, IV, dan V selalu berbeda karena perbedaan level kesulitan materi dan tahapan PjBL. Tsabitah (2016) menyatakan bahwa kesiapan belajar berpengaruh terhadap proses pembelajaran. Setelah pertemuan ke tiga, siswa mulai bisa mengikuti alur 
pembelajaran dengan model PjBL terbimbing. Antusias siswa dalam mengikuti pelajaran semakin terlihat. Hal tersebut sesuai dengan pernyataan Sumarni (2015), bahwa model pembelajaran proyek dapat menciptakan pembelajaran yang menyenangkan dan menurunkan tingkat kecemasan siswa dalam proses belajar mengajar. Besarnya peningkatan keaktifan siswa setelah diuji menggunakan N-Gain dapat dilihat pada Tabel 1 .

Tabel 1. Hasil Analisis N-Gain Keaktifan Siswa

\begin{tabular}{ccccc}
\hline \multirow{2}{*}{ Komponen } & \multicolumn{4}{c}{ N-Gain } \\
\cline { 2 - 5 } Skor & P1-P2 & P2-P3 & P3-P4 & P4-P5 \\
\hline \multirow{2}{*}{ Kriteria } & $-0,7$ & 0,2 & 0,2 & 0,2 \\
& Terjadi & Rendah & Rendah & Rendah \\
\hline
\end{tabular}

Keterangan:

P1-P2 = pertemuan 1 sampai pertemuan 2

$\mathrm{P} 2-\mathrm{P} 3=$ pertemuan 2 sampai pertemuan 3

$\mathrm{P} 3-\mathrm{P} 4=$ pertemuan 3 sampai pertemuan 4

P4-P5 = pertemuan 4 sampai pertemuan 5

Tabel 1 menunjukkan adanya penurunan keaktifan siswa dari pertemuan pertama ke pertemuan ke dua. Akan tetapi, penurunan keaktifan tidak terjadi pada semua aspek. Terdapat peningkatan keaktifan siswa pada aspek verbal activity dan mental visual activity. Pertemuan ini melibatkan siswa untuk belajar secara terbuka (open ended) (Sani, 2014). Ketika guru memberi kebebasan kepada siswa untuk membuat rancangan proyek, siswa banyak bertanya dan berkonsultasi terkait rancangan proyek yang dibuat. Hal tersebut membuat siswa percaya diri dalam mempresentasikan rancangan proyek di depan kelas, sehingga aktivitas verbal dan mental meningkat.

Aspek keaktifan siswa yang mengalami peningkatan bertambah dari pertemuan II ke pertemuan III, yaitu visual activity, writing activity, dan mental visual activity. Pertemuan ke tiga menuntut siswa untuk membuat proyek sesuai dengan rancangan yang telah ditentukan sebelumnya. Guru memonitoring/mengawasi proyek, memberi dorongan kepada siswa untuk bekerja efektif dan efisien dalam kelompok, saling membantu, dan memiliki tanggung jawab sesuai peran yang ditugaskan oleh kelompok (Sani, 2014).

Pada pertemuan III ke pertemuan IV, aspek keaktifan yang meningkat juga bertambah menjadi visual activity, verbal activity, listening activity, dan mental visual activity. Peningkatan aspek keaktifan siswa paling banyak terjadi pada pertemuan ini. Antusias siswa terhadap proyek yang telah dibuat 
membuat siswa semangat dalam memperhatikan, mendengarkan, dan melakukan percobaan. Selain itu, percobaan yang telah dilakukan membuat siswa aktif bertanya kepada guru. Hal ini sesuai dengan penelitian Fitrianingrum \& Sarwi (2016) dan Carnawi \& Sudarmin, (2017) yang menyatakan bahwa model PjBL berbasis eksperimen dapat meningkatkan kinerja siswa.

Pertemuan IV ke pertemuan V terjadi peningkatan; akan tetapi, peningkatan terjadi hanya pada aspek verbal activity, listening activity, dan writting activity. Pada pertemuan terakhir, guru meminta siswa mempresentasikan proyek dan mengerjakan post-test. Keaktifan siswa pada pertemuan ini terlihat paling banyak ketika siswa melakukan presentasi. Sudjana (2009) menyatakan bahwa keaktifan dapat dilihat ketika kelompok tersebut menggunakan kesempatan yang diberikan guru dan menjelaskan apa yang telah diperoleh dalam menyelesaikan proyek. Peningkatan tidak terjadi pada semua aspek. Hal tersebut disebabkan waktu pelaksanaan pada pertemuan terakhir yang terbatas sehingga membuat siswa terbatas untuk aktif di kelas. Suwardi (2012) menyatakan bahwa waktu juga mempengaruhi proses belajar dan penilaian kelas.

Berdasarkan hasil analisis data, didapatkan rata-rata peningkatan keaktifan siswa dalam kriteria rendah, karena waktu pelaksanaan yang masih kurang. Taslidere
(2012) \& Fariyani (2019) menyatakan bahwa diperlukan waktu yang lama untuk dapat merubah siswa menjadi aktif. Choiro \& Rasyad (2018) juga menyatakan bahwa keaktifan dalam pembelajaran memerlukan latihan-latihan agar siswa mampu menguasai kompetensi yang diinginkan.

Secara umum, hasil penelitian ini menunjukkan terjadi peningkatan keaktifan siswa dengan penerapan model PjBL. Hasil ini sesuai dengan penelitian Wijanarko \& Supardi (2017) yang menyatakan bahwa PjBL terbimbing dapat meningkatkan keaktifan siswa terutama dalam bekerjasama dengan kelompok.

\section{Pemahaman Konsep Siswa}

Peningkatan pemahaman konsep siswa diukur dari nilai pretest dan posttest yang terdiri atas tujuh indikator pemahaman konsep, meliputi: interpretasi, membandingkan, mencontohkan, mengklasifikasikan, menjelaskan, menggeneralisasikan, dan inferensi. Hasil uji N-Gain pemahaman konsep siswa ditunjukkan pada Tabel 2.

Siswa mengalami peningkatan pada setiap indikator pemahaman konsep. Permasalahan yang diberikan guru dapat memancing siswa untuk bertanya terkait permasalahan tersebut, kemudian guru membimbing siswa dengan cara berdiskusi bersama. Adanya 
bimbingan membuat siswa mampu mandiri dalam menyelesaikan masalah yang lain (Wijanarko \& Supardi, 2017; Fariyani et al., 2020).

Indikator interpretasi mengalami peningkatan dengan kategori rendah, karena kegiatan pembelajaran $\mathrm{PjBL}$ masih terbatas untuk mengajak siswa dalam menginterpretasi konsep. Selain itu, banyak siswa yang lupa materi yang pernah dijelaskan. Lestari (2011) dalam penelitiannya menyatakan bahwa kemampuan siswa yang rendah dikarenakan lemahnya daya ingat siswa. Oleh karena itu, diperlukan banyak latihan soal agar daya ingat siswa lebih baik dan terbiasa mengerjakan soal interpretasi.

Tabel 2. Hasil Uji N-Gain Pemahaman Konsep Siswa

\begin{tabular}{lccccc}
\hline \multicolumn{1}{c}{ Indikator } & Pre-test & Post-test & N-Gain & Rata-rata & Kriteria \\
\hline Pemahaman Konsep & 29,55 & 32,95 & 0,05 & & \\
Membretasi & 26,36 & 55,68 & 0,30 & & \\
Mencontohkan & 54,55 & 57,95 & 0,07 & & \\
Mengklasifikasikan & 0 & 39,77 & 0,40 & 0,22 & rendah \\
Menjelaskan & 52,27 & 65,91 & 0,29 & & \\
Menggeneralisasikan & 7,95 & 46,59 & 0,42 & & \\
Inferensi & 6,82 & 11,36 & 0,05 & & \\
\hline
\end{tabular}

Indikator membandingkan mengalami peningkatan dengan kategori sedang. Hal ini menunjukkan bahwa peningkatan kemampuan siswa untuk mencari hubungan antara dua ide, objek, atau hal-hal serupa dipengaruhi oleh model $\mathrm{PjBL}$ terbimbing. Proyek yang dikerjakan membuat siswa mampu membandingkan hasil yang didapat dengan proyek teman yang lain. Fitrianingrum \& Sarwi (2016) dalam penelitiannya juga menyatakan bahwa peningkatan kemampuan siswa didukung oleh produk yang dibuat. Indikator mencontohkan mengalami peningkatan dengan kategori rendah. Kemampuan siswa yang rendah dalam menemukan contoh lain salah satunya disebabkan daya ingat siswa yang lemah dan sikap siswa yang tergesa-gesa dalam mengerjakan soal (Lestari, 2011).

Indikator mengklasifikasikan mengalami peningkatan dalam kategori sedang karena siswa mampu menentukan sesuatu yang dimiliki oleh suatu kategori. Wijanarko \& Supardi (2017) menyatakan bahwa adanya bimbingan dalam model PjBL dapat membantu siswa mandiri dalam menyelesaikan masalah yang lain. Adanya bimbingan juga menuntut siswa untuk aktif di kelas. Keaktifan siswa mampu membuat siswa menemukan sendiri dan membangun konsep-konsep ilmiah (Slavin, 2011). 
Indikator menjelaskan mengalami peningkatan dengan kategori rendah. Hal ini menunjukkan bahwa peningkatan kemampuan siswa untuk menjelaskan sebab akibat dari suatu sistem hanya sedikit dipengaruhi oleh model PjBL terbimbing. Ketika siswa presentasi di depan kelas, kemampuan siswa menjelaskan materi menjadi bertambah. Ditambah lagi ketika ada siswa lain yang bertanya, maka akan menjadi bahan diskusi bersama antara guru dan siswa. Akan tetapi, tidak semua kelompok maju presentasi. Oleh karena itu, peningkatan yang didapatkan kurang memuaskan.

Indikator menggeneralisasikan ini mengalami peningkatan dengan kategori sedang, karena siswa sudah terlatih mengeneralisasikan informasi. Hal ini menunjukkan bahwa peningkatan kemampuan siswa untuk menggeneralisasikan tema-tema umum, dipengaruhi oleh model PjBL terbimbing.

Indikator inferensi mengalami peningkatan rendah karena siswa belum terbiasa menyimpulkan materi. Hal ini menunjukkan bahwa model PjBL terbimbing hanya memberi peningkatan yang rendah untuk menggambarkan kesimpulan logis. Diperlukan latihan soal yang banyak untuk mencapai kemampuan ini. Keterbatasan waktu dalam penelitian ini menjadi penghalang siswa untuk banyak melakukan latihan soal. Sumarni (2015) dalam penelitiannya menyatakan bahwa diperlukan waktu yang banyak untuk memecahkan permasalahan yang kompleks.

Hasil uji wilcoxon match pairs diperoleh nilai signifikansi keaktifan dan pemahman konsep siswa sebesar 0,041 dan 0,000 $(<0,05)$. Hasil tersebut menunjukkan terdapat peningkatan pemahaman konsep yang signifikan setelah dilaksanakan model PjBL terbimbing.

Rata-rata peningkatan pemahaman konsep siswa rendah dikarenakan faktor internal dan eksternal (Suwardi, 2012). Faktor internal pada penelitian ini yaitu kurangnya keinginan siswa (minat) untuk belajar. Tanpa minat siswa dalam kegiatan belajar mengajar, maka tidak ada kemungkinan untuk mencapai pengetahuan karena prestasi siswa tergantung pada kebutuhan, minat, praktik, dan keseriusan siswa dalam belajar (Acharya, 2017; Azka et al., 2020). Oleh karena itu, perlu adanya bimbingan yang besar dari guru (Abraham et al., 2011). Bimbingan dalam penelitian ini antara lain berupa petunjuk menguraikan masalah, mengerjakan proyek, dan membuat penjadwalan; yang disertai dorongan dan ajakan agar siswa mau mengerjakan apa yang ditugaskan guru. Faktor lain yang mempengaruhi

pemahaman konsep siswa yaitu kemampuan siswa itu sendiri. Sumarni, Wardani, \& Sudarmin (2016) menyatakan bahwa pembelajaran dengan menciptakan produk yang 
tidak diimbangi oleh kemampuan siswa dapat menyebabkan hasil belajar kurang optimal. Acharya (2017) juga menyatakan bahwa siswa yang memiliki pengetahuan awal yang kurang dan tidak mau belajar akan gagal dalam pelajaran tersebut di semua tingkat.

\section{KESIMPULAN}

Berdasarkan hasil penelitian dan pembahasan, dapat disimpulkan bahwa keaktifan siswa setelah menggunakan model Project Based Learning (PjBL) terbimbing pada materi Momentum, Impuls, dan Tumbukan mengalami peningkatan yang rendah dengan N-Gain sebesar 0,20. Hasil perhitungan perbedaan nilai observasi keaktifan pertemuan pertama dan pertemuan ke lima menghasilkan taraf signifikan sebesar 0,041 yang lebih kecil dari 0,05 sehingga dapat disimpulkan bahwa keaktifan siswa mengalami perbedaan (terjadi peningkatan) yang signifikan setelah menggunakan model PjBL terbimbing. Pemahaman konsep siswa mengalami peningkatan yang rendah dengan N-Gain sebesar 0,22 . Hasil perhitungan perbedaan nilai pretest dan posttest menghasilkan taraf signifikan sebesar 0,00 yang lebih kecil dari 0,05 sehingga dapat disimpulkan bahwa pemahaman konsep siswa mengalami perbedaan (terjadi peningkatan) yang signifikan setelah menggunakan model PjBL terbimbing.

\section{DAFTAR PUSTAKA}

Abraham, RR, M. Fisher, A. Kamath, T.A. Izzati, S. Nabila, \& N. . A. 2011. Exploring First Year Undergraduate Medical Students Self-Directed Learning Readiness to Physiology. Advances in Physiology Education, 35(4): 393-395.

Acharya, B. R. 2017. Factors Affecting Difficulty in Learning Mathematics by Mathematics Learners. International Journal of Elementary Education, 6(2): 815.

Afifah, R., Sugianto, \& B. A. 2017. Penerapan Pendekatan Pembelajaran Jelajah Alam Sekitar (JAS) terhadap Pemahaman Konsep Siswa. Unnes Physics Education Journal, 6(2): 56-63.

Azka, M., Sudarmanto, A., \& Yusufiyah, H. K. N. (2020). Pengaruh Metode Eksperimen Terhadap Motivasi dan Hasil Belajar Siswa Kelas X pada Materi Gerak Lurus. Physics Education Research Journal, 2(1): $\quad 9-18$. https://doi.org/10.21580/p erj.2020.2.1.3948.

Carnawi, Sudarmin, \& N. W. 2017. Application of Project Based Learning (PBL) Model From Materials of Salt Hydrolisis to Encourage Students' 
Entrepreneurship

Behaviour. International Jurnal of Active Learning, 2(1): 50-58.

Choiro, U. D., A. Rasyad, \& S. 2018. Keaktifan Belajar Peserta Didik pada Transfer Pengetahuan Kerajinan Pandai Besi. Jurnal Pendidikan Teori, Penelitian, dan Pengembangan, 3(4): 486490.

Fariyani, Q. 2019. Model

Pembelajaran Kooperatif

Jigsaw untuk Meningkatkan

Keaktifan dan Hasil Belajar

Siswa MTs Kelas VIII. Jurnal

Penelitian Pembelajaran Fisika, 10(2): 133-138.

https://doi.org/10.26877/jp 2f.v10i2.4026.

Fariyani, Q., Mubarok, F. K., Masfu'ah, S., \& Syukur, F. (2020). Pedagogical Content Knowledge of Pre-service Physics Teachers. Jurnal Ilmiah Pendidikan Fisika AlBiruni, 9(1): 99-107. https://doi.org/10.24042/ji pfalbiruni.v9i1.3409.

Fitrianingrum, A. M. \& Sarwi. 2016.

Keefektifan Project Based Learning Berbasis Eksperimen pada

Penguasaan Konsep dan Kinerja Siswa SMA. Unnes Physics Education Journal, 5(2): 20-28.

Irfianti, M. D. \& S. Khanafiyah 2016.

Perkembangan Karakter

Peduli Lingkungan melalui Model Experiental Learning.
Unnes Physisc Education Journal, 5(3): 72-79.

Julianti, U \& Wahyono. 2016. Pengaruh Model Project Based Learning Berbantuan Multimedia terhadap Pemahaman Konsep Siswa pada Materi Tekanan Zat cair di SMPN 18 Palu. Jurnal Pendidikan Fisika Tadaluko, 4(3): 7-11.

Late, M. N., Sutopo, L. Y. 2017. Peningkatan Pemahaman Konsep Tekanan Hidrostatis dan Hukum Archimedes Siswa SMP Melalui Pembelajaran Dicovery. Jurnal Pendidikan Teori, Penelitian, dan Pengembangan, 2(9): 12151219.

Lestari, R. 2011. Analisis Kesalahan dalam Menyelesaikan Soal Faktorisasi Suku Aljabar Pada Siswa Kelas VIII SMP Negeri 1 Jaten Tahun Ajaran 2010/2011. Tesis. Surakarta: UNS.

Martin, M. O. \& Mullis, I. 2012. International Association for the Evaluation of Educational Achievement (IEA) Timss 2011 International Results in Science. Boston: TIMSS \& PIRLS International Study Center.

Purwati, S., S. K. Handayanto, \& S. Z. 2016. Korelasi Antara Penalaran Ilmiah dan Pemahaman Konsep Siswa pada Materi Usaha dan Energi. Prosiding Seminar 
Nasional Pendidikan IPA

Pascasarjana UM. Malang:

Universitas Negeri Malang. Ramadhani, F., S. Santosa, \& N. 2013. Upaya Peningkatan Kualitas Pembelajaran Akuntansi Melalui Penerapan Model Pembelajaran Berbasis Proyek (Project Based Learning). Jurnal Pendidikan Universitas Negeri Sebelas Maret, 1(1): 1-12.

Sani, R. 2014. Pembelajaran Saintek untuk Implementasi Kurikulum 2013. Jakarta: Bumi Aksara.

Sari, D. N. \& Sutikno. 2015. Pengaruh Pembelajaran Berbasis Proyek terhadap Kreatifitas Siswa melalui Elektroskop Sederhana. Prosiding Seminar Nasional Fisika. Jakarta: Univeristas Negeri Jakarta.

Septialamsyah, M. A. 2014. Pengaruh Kecemasan dan

Keaktifan Belajar Siswa Terhadap Kemampuan Pemahaman Konsep Melalui Model Pembelajaran Resource Based Learning Materi Prisma dan Limas Kelas VIII SMP Negeri 2 Wiradesa. Jurnal Ilmiah Pendidikan Matematika, 2(2): 57-67.

Slavin, R. E. 2011. Educational Psychology: Theory dan Practice (Sixth). Boston: Allyn \& Bacon.

Sudjana, N. 2009. Penilaian Hasil
Belajar Mengajar. Bandung: PT Remaja Rosdakarya.

Sumarni, W., S. Wardani, \& Sudarmin. 2016. Project Based Learning (PBL) to Improve Psychomotoric Skills: A classrom Action Research. Jurnal Pendidikan IPA Indonesia, 5(2): 157-163.

Sumarni, W. 2015. The Strengths and Weaknesses of the Implementation of Project Based Learning: A Review. International Journal of Science and Research (IJSR), 4(3): 478-484.

Sunyoung, H., R. \& Capraro. 2012. How Science, Technology, Engineering, and Mathematics (STEM) Project Based Learning (PBL) Affect High, Middle, and Low Achievers Differently: The Impact of Student Factors on Achievement. International Journal of Sains and Mathematics Education, 1-20.

Suranti, N. M. Y., Gunawan, \& H. S. 2016. Pengaruh Model Project Based Learning Berbantuan Media Virtual terhadap Penguasaan Konsep Peserta Didik pada Materi Alat-alat Optik. Jurnal Pendidikan Fisika Dan Teknologi, 2(2): 73-79.

Suseno, N. 2014. Pemetaan Analogi Pada Konsep Abstrak Fisika. Jurnal Pendidikan Fisika, 1-10. Suwardi, D. R. 2012. Faktor-faktor Yang Mempengaruhi Hasil Belajar Siswa Kompetensi 
Dasar Ayat Jurnal Penyesuaian Mata Pelajaran Akuntansi Kelas XI IPS di SMAN 1 BAE. Economic Education Analysis Journal, 1(2): 1-7.

Taslidere, E. \& A. E. 2012. The Relative Effetiveness of Integrated Reading Study Strategy and Conceptual Physics Approach. Res Scientific Education, 42: 181199.

Tsabitah, D. 2016. Peran Kesiapan Belajar dalam Memediasi Pengaruh Kesiapan Belajar dan Fasilitas Belajar terhadap Hasil Belajar Akuntansi. Economic Education Analysis Journal, 5(1): 72-84.

Wibowo, N. 2016. Upaya Peningkatan Keaktifan Siswa Melalui Pembelajaran Berdasarkan Gaya Belajar di SMK Negeri 1 Saptosari. Jurnal Electronic,Informatics, and Vocational Education (ELINVO), 1(2): 128-139.

Wijanarko, A.I. \& K.I. Supardi. 2017. Keefektifan Model Project Based Leaarning Terbimbing untuk Meningkatkan Keterampilan Proses Sains dan Hasil Belajar IPA. Journal of Primary Education, 6(2): 120125.

Winarti, T. 2014. Pembelajaran Praktikum Berorientasi Proyek untuk Meningkatkan Keterampilan Proses Sains dan Pemahaman Konsep. Jurnal Inovasi Pendidikan Kimia, 8(2): 1409-1420.

Yulianto, A. \& A. Fatchan. 2017. Penerapan Model Pembelajaran Project Based Learning berbasis Lesson Study untuk meningkatkan Keaktifan Belajar Siswa. Jurnal Pendidikan Teori, Penelitian, dan Pengembangan, 2(3): 448-453. 
Phy. Educ. Res. J. Vol. 2 No. 2 (2020), 69 - 82 